\title{
Perancangan Alat Simulasi SILO VISCOSE Otomatis Berbasis Kendali Elektro Pneumatik
}

\author{
Muhammad Yugi Wibowo ${ }^{1}$, Sandy Bhawana Mulia² \\ ${ }^{1}$ Teknik Elektro, Politeknik Enjinering Indorama \\ ${ }^{2}$ Teknik Otomasi Manufaktur dan Mekatronika, Politeknik Manufaktur Bandung \\ Email: yugiwibowo0@gmail.com ${ }^{1}$
}

Informasi Artikel: ABSTRAK

Received:

7 Agustus 2019

Accepted :

23 September 2019

Available

23 Desember 2019
Alat simulasi silo vicose merupakan suatu proses produksi yang dimana bertujuan untuk mengalirkan bubur kertas, dan proses produksi tersebut menggunakan kendali pneumatik sebagai pengganti dan meringankan kerja manusia secara langsung. Dalam makalah ini dirancang sistem kontrol untuk alat simulasi silo viscose dengan sistem close loop. Peralatan sistem kontrol yang dirancang menggunakan komponen sensor pelampung level air atau yang biasa disebut dengan water level float sensor. Water level float sensor digunakan untuk mendeteksi level penuh pada silo yang kemudian memberikan sinyal langsung ke PLC kemudian akan diproses dan keluar output ke solenoid valve untuk menggerakkan silinder yang digunakan untuk membuka dan menutup slide gate (pintu geser) pada saluran silo. Metode yang digunakan dalam pembuatan alat ini yaitu perancangan desain kontruksi, perencanaan sistem elektro pneumatik, dan perakitan. Berdasarkan pengujian yang sudah dilakukan, sistem dapat bekerja dengan baik dan sesuai dengan perancangan.

\section{ABSTRACT}

The vicose silo simulation tool is a production process that is intended to drain the pulp, and the production process uses pneumatic control as a rescue and direct human work. In this paper a control system is designed for a viscose silo simulation tool with a close loop system. Control system equipment that is designed using a water level float sensor component or commonly referred to as a water level float sensor. The float sensor water level is used to detect the full level of the silo which then gives a signal directly to the PLC and will then be processed and output will be output to the solenoid valve to move the cylinder used to open and close the slide gate on the silo channel. The method used in making this tool is construction design, electro pneumatic system planning, and assembly. Based on testing that has been done, the system can work well and in accordance with the design. 


\section{Pendahuluan}

Peralatan yang dirancang oleh industri manufaktur diharapkan mampu menghasilkan produk yang bagus, baik dari sisi kuantitas maupun kualitas [1]. Dari sisi kuantitas, peralatan tersebut mampu menghasilkan produk secara masal dan menghasilkan produksi dalam jumlah besar. Sedangkan kualitas, produk yang diproduksi oleh suatu industri manufaktur memiliki mutu dan kemampuan yang baik dimana sesuai dengan spesifikasi rancangan. Karena meningkatnya kebutuhan pasar maka sekarang ini seluruh alat produksi telah menggunakan peralatan yang serba otomatis. Karena proses secara otomatis dengan perangkat elektronik dapat mengatasi masalah tersebut dengan keuntungan berupa mengurangi biaya, mempersingkat waktu dan meningkatkan kualitas hasil produksi [2].

Pada makalah ini dipaparkan mengenai alat simulasi silo viscose menggunakan kendali elektro-pneumatik, yang banyak digunakan oleh industri manufaktur khususnya di sektor tekstil. Elektro pneumatik merupakan pengembangan dari pneumatik, dimana prinsip kerjanya memilih energi pneumatik sebagai media kerja (tenaga penggerak) sedangkan media kontrolnya mempergunakan sinyal elektrik ataupun elektronik [3]. Selain itu, untuk proses pengontrolannya penulis menggunakan PLC (Programmable Logic Controller) yang dapat diintegrasikan dengan berbagai komponen sehingga memudahkan user dalam penggunaannya. Karena sebagian besar PLC tidak dilengkapi dengan monitor, tetapi dilengkapi dengan peripheral port yang berfungsi untuk memasukkan program sekaligus memonitor data atau program [4].

Dalam proses produksi di industri saat ini, PLC dan kendali elektro pneumatik merupakan perangkat sistem otomatis yang paling banyak digunakan [5]. Oleh karena itu, untuk mewujudkan sistem atau proses otomasi ini penulis akan merancang sebuah alat yang akan mensimulasikan kontrol pada silo viscose dalam proses produksi di sektor tekstil.

\section{METOde PENELITIAN}

Metode penelitian menjelaskan rancangan alat simulasi silo viscose dan pengujian yang dilakukan pada solenoid valve. Karena solenoid valve hanya menkonsumsi sedikit energi [2]. Pengujian ini akan dilakukan dengan cara melakukan pengisian bubur kertas ke dalam silo berkapasitas 3.4 liter, kemudian dicatat waktu pengisian tersebut. Kemudian dilanjutkan dengan melakukan pengukuran tegangan dan arus pada solenoid valve saat dilakukan pengisian.

\subsection{Rancangan Alat Simulasi Silo Viscose}

Pada Gambar 1 di bawah ini, kontruksi silo utama penampung bubur kertas dengan kapasitas 13.5 liter sedangkan silo 1 dan silo 2 untuk pendistrubusian berkapasitas 3.4 liter yang nanti pada bubur kertas ini akan disalurkan lagi ke dalam wadah secara bergantian. Slide gate pada setiap silo yang berkerja dengan cara bergeser atau membuka dan menutup silo berfungsi untuk mengeluarkan bubur kertas dimana slide gate tersebut digerakan oleh silinder pneumatik yang bertekanan 6 bar, lalu terdapat panel listrik berukuran 30 x $40 \mathrm{~cm}$ yang didalamnya terdapat komponen sistem kontrol listrik seperti PLC dan terdapat power supply 24 VDC $2.5 \mathrm{~A}$. 


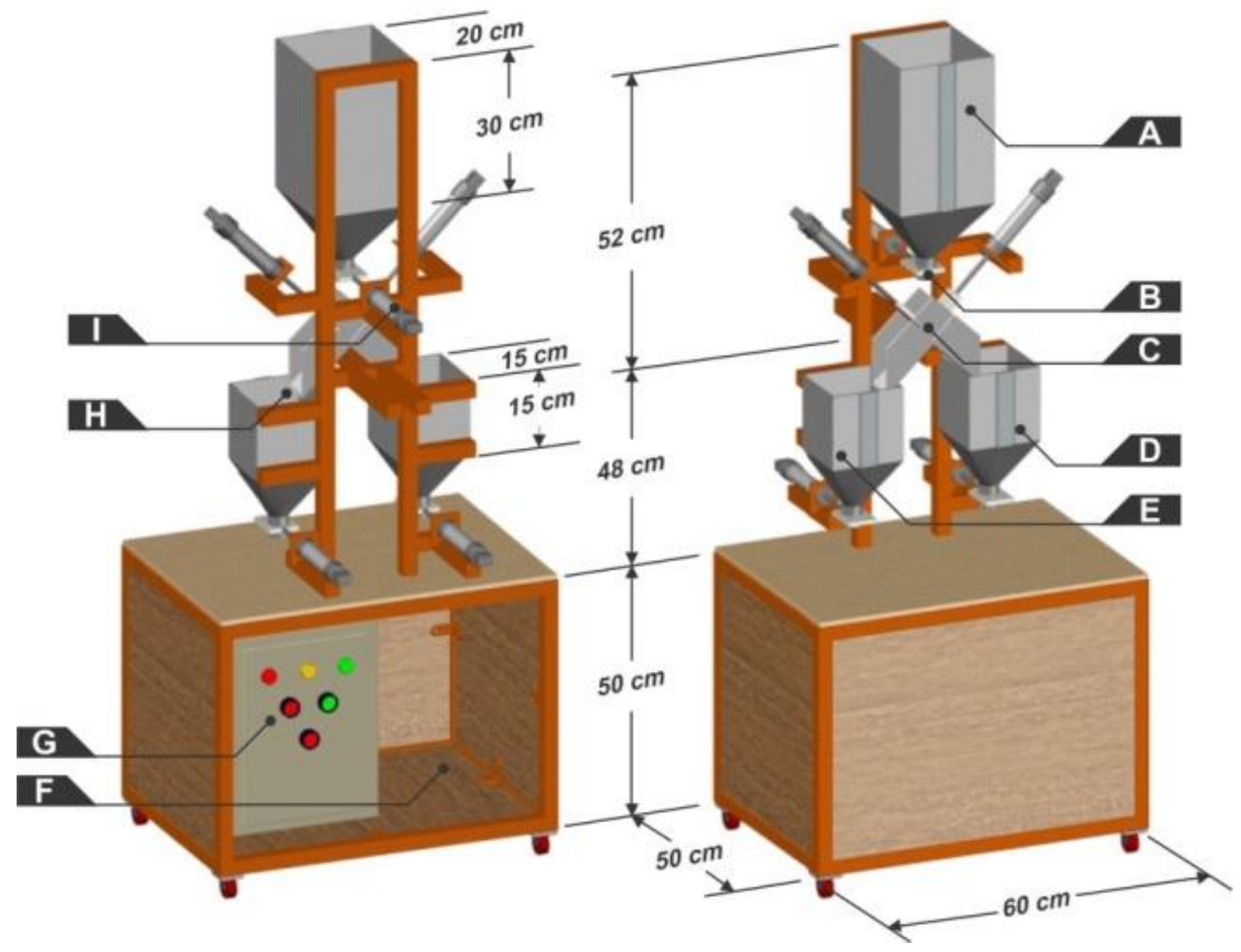

Gambar 1. Rancangan Konstruksi Alat Simulasi Silo Viscose

Keterangan Gambar:
A. Silo utama
B. Slide gate (Pintu geser) silo
C. Jalur pengalih
D. Silo 2
E. Silo 1
F. Ruang kontrol solenoid valve
G. Panel listrik
H. Water level float sensor
I. Silinder

Solenoid valve yang digunakan memiliki spesifikasi sebagai berikut:

Tabel 1. Spesifikasi Solenoid Valve

\begin{tabular}{llll}
\hline a. & Type & $=$ & $4 \mathrm{~V} 210-08$ AirTAC \\
\hline b. & Model & $=$ & $5 / 2$ way \\
\hline c. & Port Size & $=$ & $1 / 4$ Inchi \\
\hline d. Operating Pressure & $=$ & $0.15-0.8 \mathrm{Mpa}$ \\
\hline e. & Temperature & $=$ & $-20-70{ }^{\circ} \mathrm{C}$ \\
\hline
\end{tabular}


Adapun solenoid valve yang digunakan ditunjukkan pada Gambar 2 di bawah. Solenoid valve $5 / 2$ yang digunakan pada alat simulasi silo viscose berfungsi untuk mengatur kerja silinder melalui pengaturan arah aliran udara dan menuju silinder slide gate. Valve ini dapat melakukan pengaturan arah aliran udara bahkan dari dua arah yaitu, arah mundur dan maju yang dioperasikan secara elektrik.

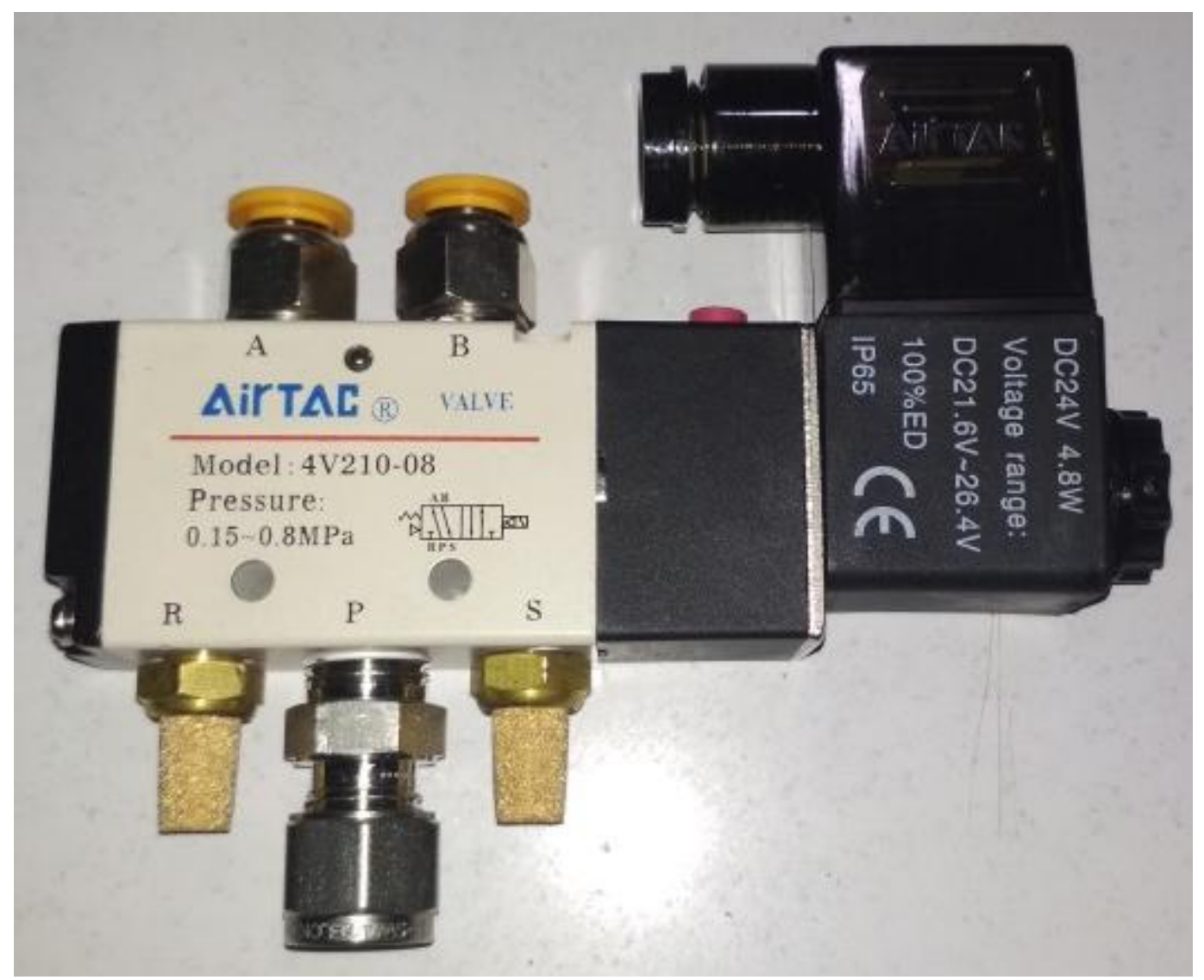

Gambar 2. Solenoid Valve 5/2

Adapun silinder double acting pada alat simulasi silo viscose digunanakan sebagai penggerak untuk membuka dan menutup slide gate pada silo, silinder ini bergerak karena adanya tekanan udara sehingga piston didalam silinder dapat bergerak maju dan mundur. Berikut spesifikasi silinder double acting yang digunakan:

Tabel 2. Spesifikasi Silinder Double Acting

\begin{tabular}{llll}
\hline a. & Model & $:$ & MAL 20 x 50 TPM \\
\hline b. & Body Material & $:$ & Alumunium Alloy \\
\hline c. & Bore Size & $:$ & $20 \mathrm{~mm}$ \\
\hline d. & Stroke & $:$ & $50 \mathrm{~mm}$ \\
\hline e. & Acting type & $:$ & Double Acting \\
\hline f. & Max. Pressure & $:$ & 0.7 Mpa (7 bar $)$ \\
\hline g. & Terperature & $:$ & $0-70$ oC
\end{tabular}


Perancangan Alat Simulasi SILO VISCOSE Otomatis Berbasis Kendali Elektro Pneumatik

\begin{tabular}{llll}
\hline h. & Speed Range & $:$ & $30-800 \mathrm{~mm} / \mathrm{s}$ \\
\hline i. & Port Size & $:$ & $1 / 8$ inchi \\
\hline
\end{tabular}

Adapun silinder double acting yang digunakan ditunjukkan pada Gambar 3.

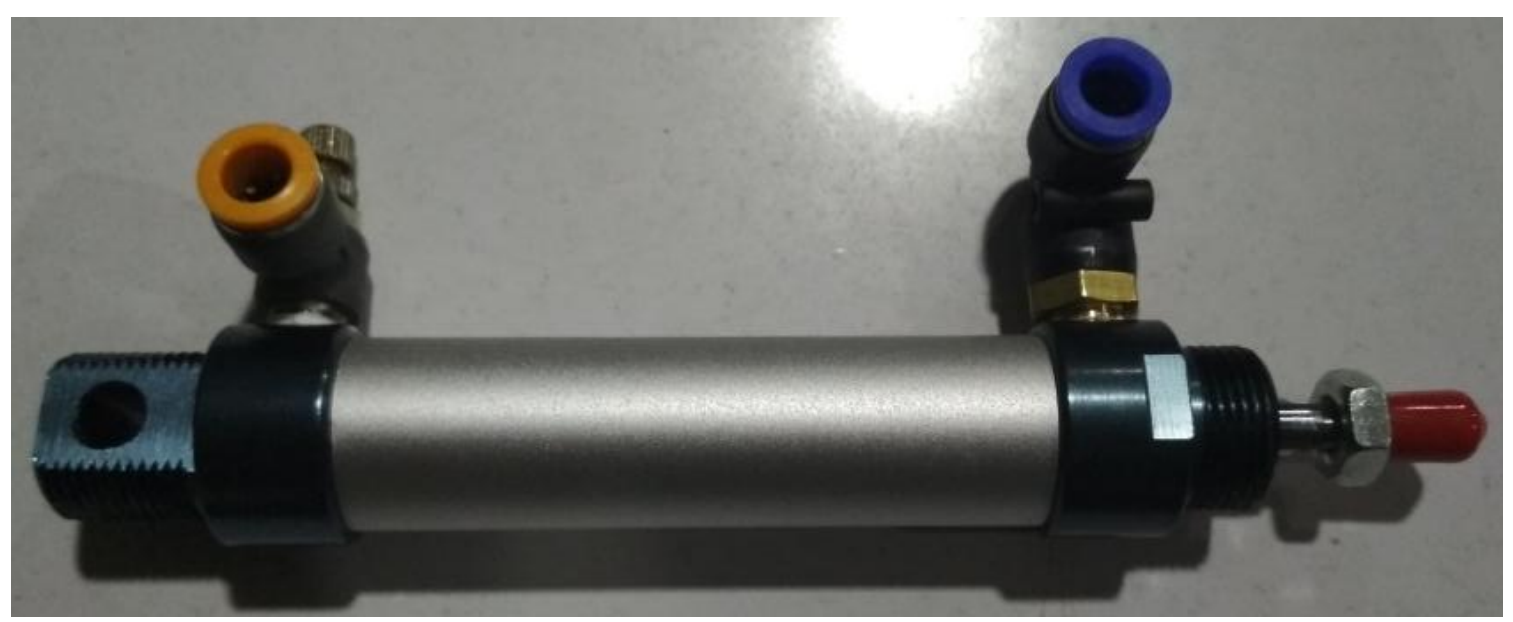

Gambar 3. Silinder Double Acting

Silinder pada alat simulasi silo viscose ini dicouple dengan slide gate pada silo, agar dapat bergerak menutup dan membuka untuk mengalirkan bubur kertas. Berikut adalah Gambar 4 slide gate silo yang telah dicouple dengan silinder pada silo utama, silo 1, dan silo 2.

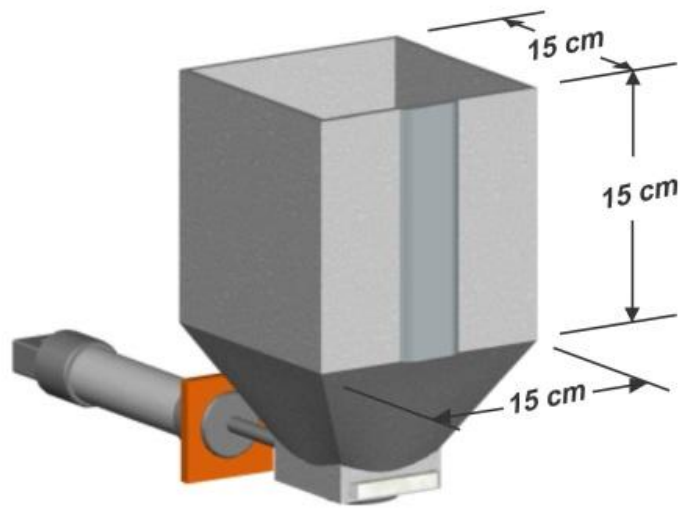

(a) Silo 1 dan 2

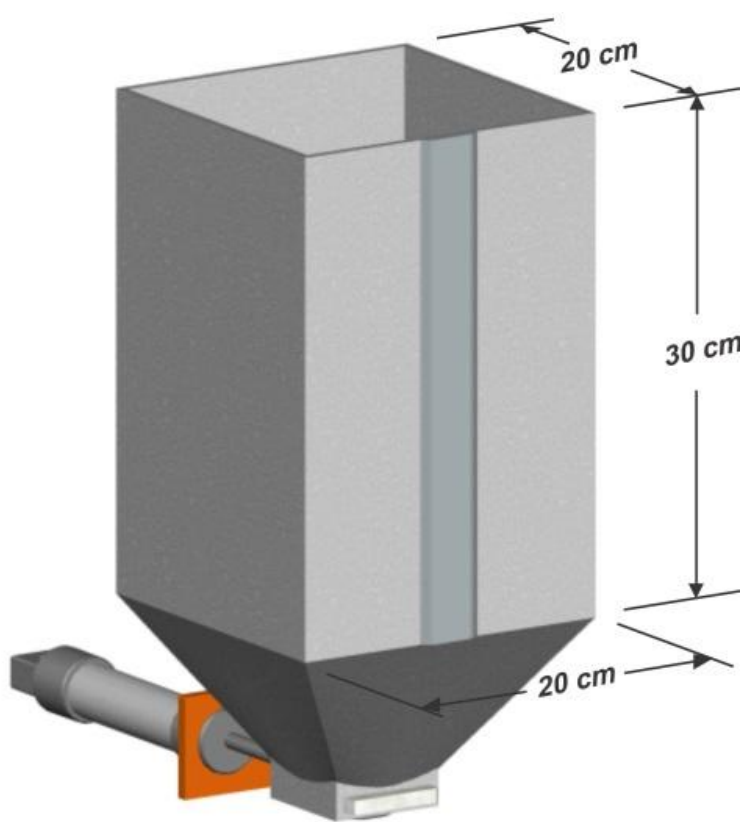

(b) Silo Utama

Gambar 4. Slide Gate Silo 


\subsection{Pengujian Kendali Elektro Pneumatik}

Pengujian kendali elektro pneumatik dilakukan dengan cara mencari waktu pengisian silo 1 dan silo 2 dengan volume masing-masing 3.4 liter, kemudian dilanjutkan dengan mengukur tegangan dan arus pada solenoid valve yang terpasang pada papan kayu seperti pada Gambar 5.

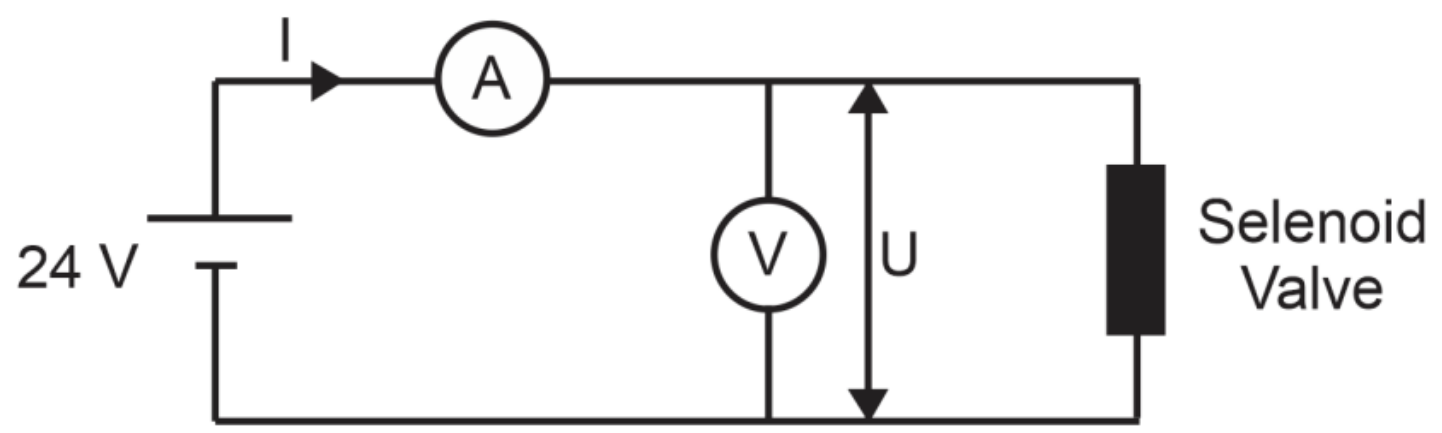

Gambar 5. Rangkaian Pengukuran Tegangan dan Arus Pada Solenoid Valve

\section{HASIL}

\subsection{Hasil Pengujian Pengisian Silo}

Pengujian pengisian silo ini dilakukan pada pada silo 1 dan silo 2 untuk mengetahui apakah silo dapat digunakan secara otomatis. Pengujian pengisian silo dilakukan dengan cara mengisi bubur kertas kedalam silo 1 dan silo 2 lalu dicatat waktu pengisian tersebut. Pengisian silo dilakukan secara 5 kali pada tiap kondisi silo utama yang berbeda, yaitu dengan isi silo utama sebanyak 12 liter, 10 liter, dan 8 liter. Hasil pengujian tersebut disajikan pada tabel 3 di bawah ini.

Tabel 3. Hasil Pengujian Pengisian Silo.

\begin{tabular}{ccccccc}
\hline \multirow{2}{*}{ No } & \multicolumn{7}{c}{ Waktu Pengisian Silo (detik) } \\
\cline { 2 - 7 } & \multicolumn{2}{c}{ 12 Liter } & \multicolumn{2}{c}{ 10 Liter } & 8 Liter \\
\cline { 2 - 7 } & Silo 1 & Silo 2 & Silo 1 & Silo 2 & Silo 1 & Silo 2 \\
\hline $\mathbf{1}$ & 277 & 311 & 288 & 318 & 302 & 400 \\
\hline $\mathbf{2}$ & 270 & 305 & 290 & 312 & 308 & 399 \\
\hline $\mathbf{3}$ & 274 & 302 & 287 & 314 & 310 & 403 \\
\hline $\mathbf{4}$ & 273 & 305 & 288 & 315 & 305 & 405 \\
\hline $\mathbf{5}$ & 272 & 307 & 285 & 315 & 304 & 394 \\
\hline Rata-Rata & $\mathbf{2 7 3 . 2}$ & $\mathbf{3 0 6 . 0}$ & $\mathbf{2 8 7 . 6}$ & $\mathbf{3 1 4 . 8}$ & $\mathbf{3 0 5 . 8}$ & $\mathbf{4 0 0 . 2}$ \\
\hline
\end{tabular}

Adapun karakteristik hasil pengujian pengisian silo menggunakan solenoid valve dapat dilihat pada Gambar 6. 
Perancangan Alat Simulasi SILO VISCOSE Otomatis Berbasis Kendali Elektro Pneumatik

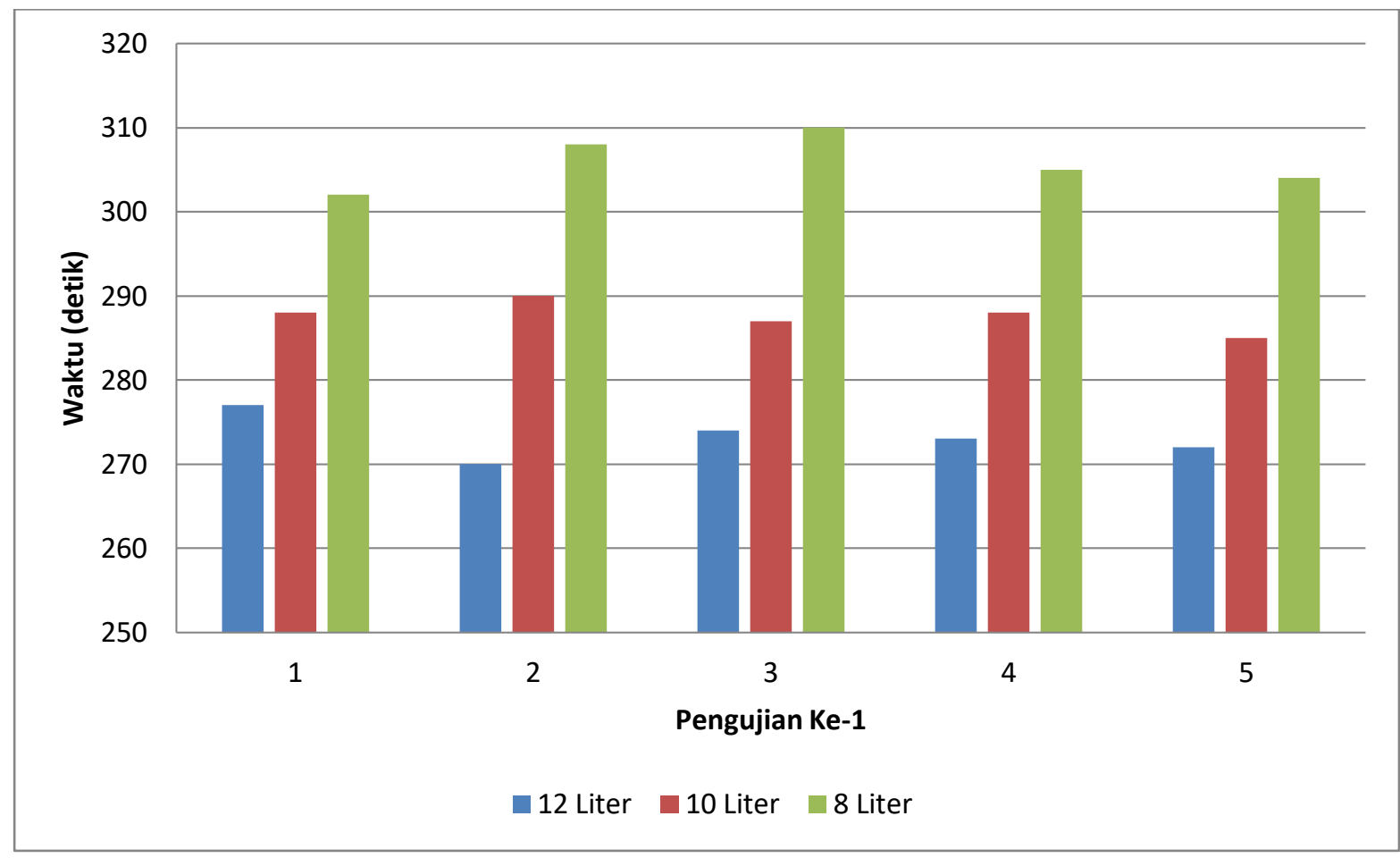

Gambar 6. Grafik Hasil Pengujian Pengisian Silo 1

Dari grafik diatas dapat diketahui bahwa semakin sedikit volume bubur kertas yang terdapat pada silo utama maka semakin lama waktu pengisian pada silo 1 . Begitu juga yang terjadi pada saat pengisian silo 2, semakin sedikit volume bubur kertas yang terdapat pada silo utama maka semakin lama waktu pengisian pada silo 2. Seperti ditunjukan pada Gambar 7.

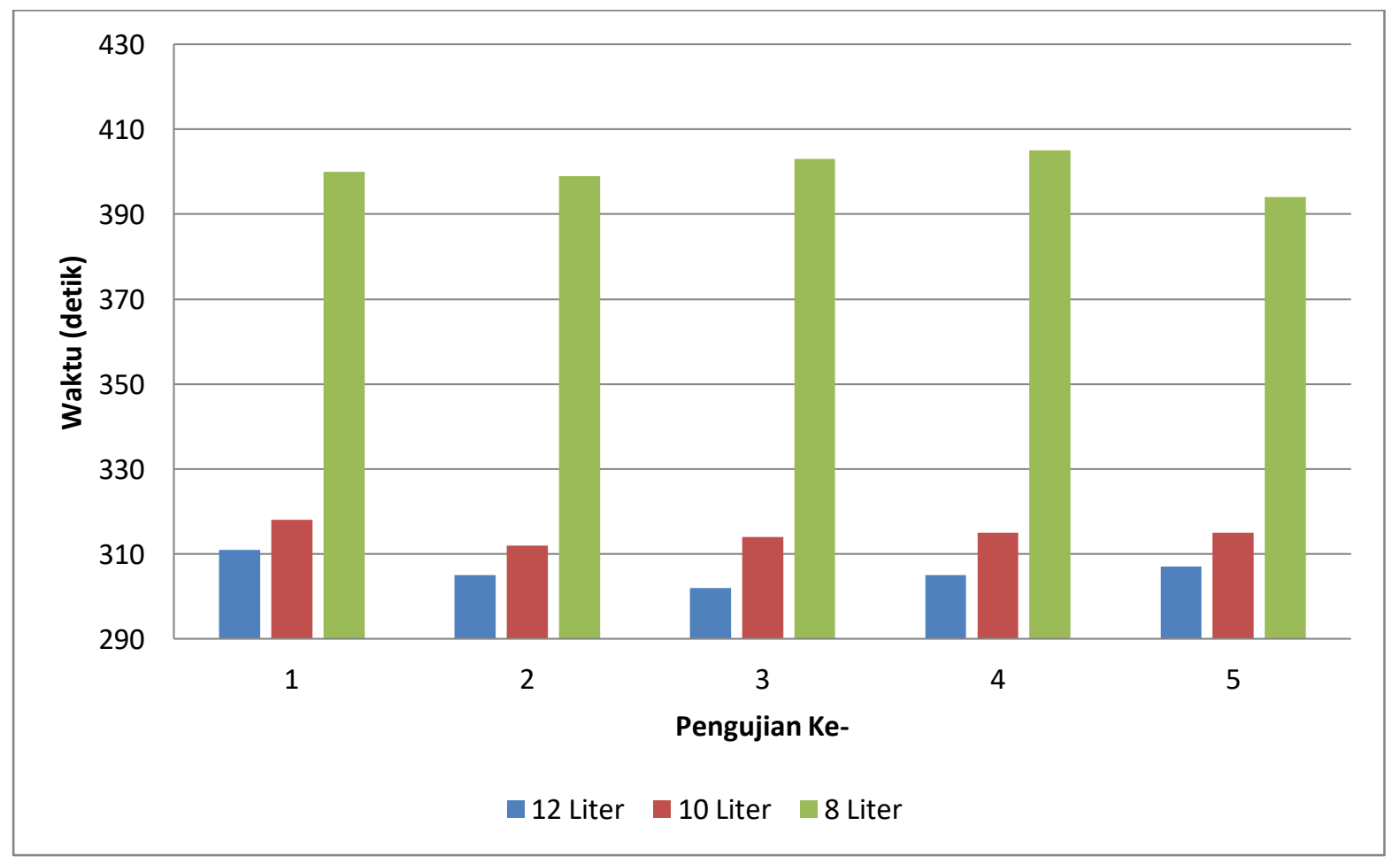

Gambar 7. Grafik Hasil Pengujian Pengisian Silo 2 
Tabel 4. Hasil Pengukuran Tegangan dan Arus Solenoid Valve.

\begin{tabular}{ccccc}
\hline \multirow{5}{*}{ No } & \multicolumn{4}{c}{ Selenoid Valve 5/2 } \\
& Arus (A) & Tegangan (V) & Arus (A) & Tegangan (V) \\
\cline { 2 - 5 } & 0.21 & 24.0 & 0.21 & 24.2 \\
\hline $\mathbf{1}$ & 0.21 & 24.0 & 0.21 & 24.1 \\
\hline $\mathbf{3}$ & 0.21 & 24.0 & 0.21 & 24.0 \\
\hline $\mathbf{4}$ & 0.21 & 23.5 & 0.21 & 24.2 \\
\hline $\mathbf{5}$ & 0.21 & 24.2 & 0.21 & 24.0 \\
\hline $\mathbf{6}$ & 0.21 & 24.0 & 0.21 & 24.2 \\
\hline $\mathbf{7}$ & 0.21 & 24.2 & 0.21 & 23.5 \\
\hline $\mathbf{8}$ & 0.21 & 24.0 & 0.21 & 24.0 \\
\hline $\mathbf{9}$ & 0.21 & 24.1 & 0.21 & 24.0 \\
\hline $\mathbf{1 0}$ & 0.21 & 24.2 & 0.21 & 24.0 \\
\hline Rata-Rata & $\mathbf{0 . 2 1}$ & $\mathbf{2 4 . 0 2}$ & $\mathbf{0 . 2 1}$ & $\mathbf{2 4 . 0 2}$ \\
\hline
\end{tabular}

\subsection{Perhitungan Debit Viscose}

Untuk menganalisa hasil pengujian pengisian silo maka diperlukan perhitungan debit bubur kertas yang keluar dari silo utama dengan menggunakan rumus sebagai berikut:

$Q=\frac{V}{t}$

Dimana:

$\mathrm{Q}=$ Debit air $(\mathrm{mL} /$ detik)

$\mathrm{V}=$ Volume botol $(\mathrm{mL})$

$\mathrm{t}=$ Waktu pengisian (detik)

Volume silo 1 dan silo 2 yang diisi adalah 3.4 liter, maka debit viscose berdasarkan hasil pengujian yang disajikan pada tabel 5 yaitu seperti tabel di bawah ini.

Tabel 5. Hasil Perhitungan Debit Viscose

\begin{tabular}{cccc}
\hline Isi Silo Utama (L) & $\begin{array}{c}\text { Volume Silo 1 } \\
(\mathbf{m L})\end{array}$ & $\begin{array}{c}\text { Waktu } \\
\text { (detik) }\end{array}$ & $\begin{array}{c}\text { Debit } \\
(\mathbf{m L} / \text { detik) }\end{array}$ \\
\hline $\mathbf{1 2}$ & 3.400 & 273,2 & 12,44 \\
\hline $\mathbf{1 0}$ & 3.400 & 287,6 & 11,82 \\
\hline $\mathbf{8}$ & 3.400 & 305,8 & 11,11 \\
\hline Isi Silo Utama (L) & $\begin{array}{c}\text { Volume Silo } \mathbf{m} \\
(\mathbf{m L})\end{array}$ & $\begin{array}{c}\text { Waktu } \\
\text { (detik) }\end{array}$ & $\begin{array}{c}\text { Debit } \\
\text { (mL/detik) }\end{array}$ \\
\hline $\mathbf{8 , 6}$ & 3.400 & 306 & 11,11 \\
\hline $\mathbf{6 , 6}$ & 3.400 & 314,8 & 10,8 \\
\hline $\mathbf{4 , 6}$ & 3.400 & 400,2 & 8,49 \\
\hline
\end{tabular}

Berdasarkan Tabel 5 di atas dapat diketahui bahwa debit viscose bertambah ketika isi silo utama semakin penuh. Hal tersebut dapat dilihat seperti pada Gambar 8 di bawah ini. 
Perancangan Alat Simulasi SILO VISCOSE Otomatis Berbasis Kendali Elektro Pneumatik

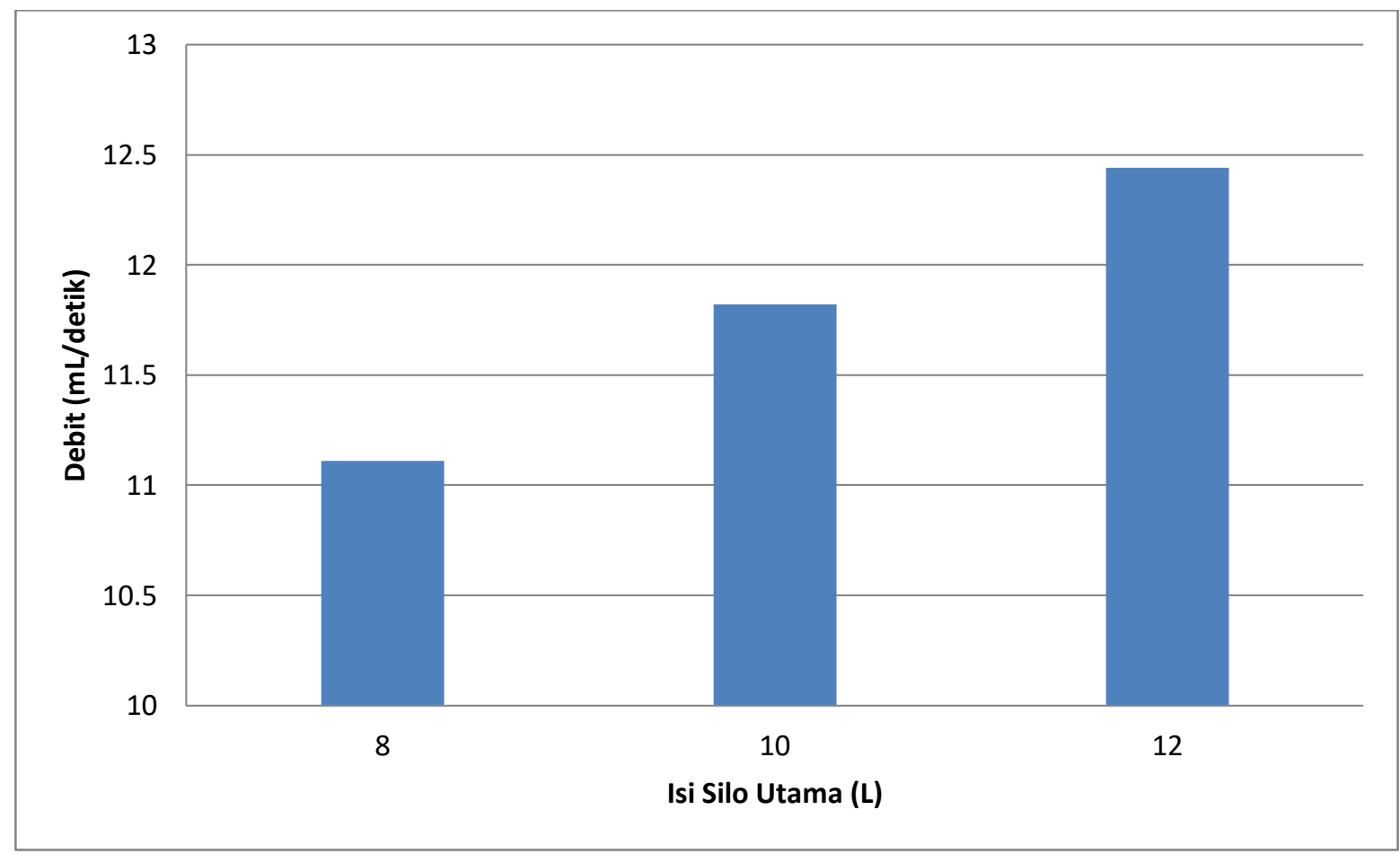

Gambar 8. Grafik Hasil Perhitungan Debit Bubur Kertas Menuju Silo 1

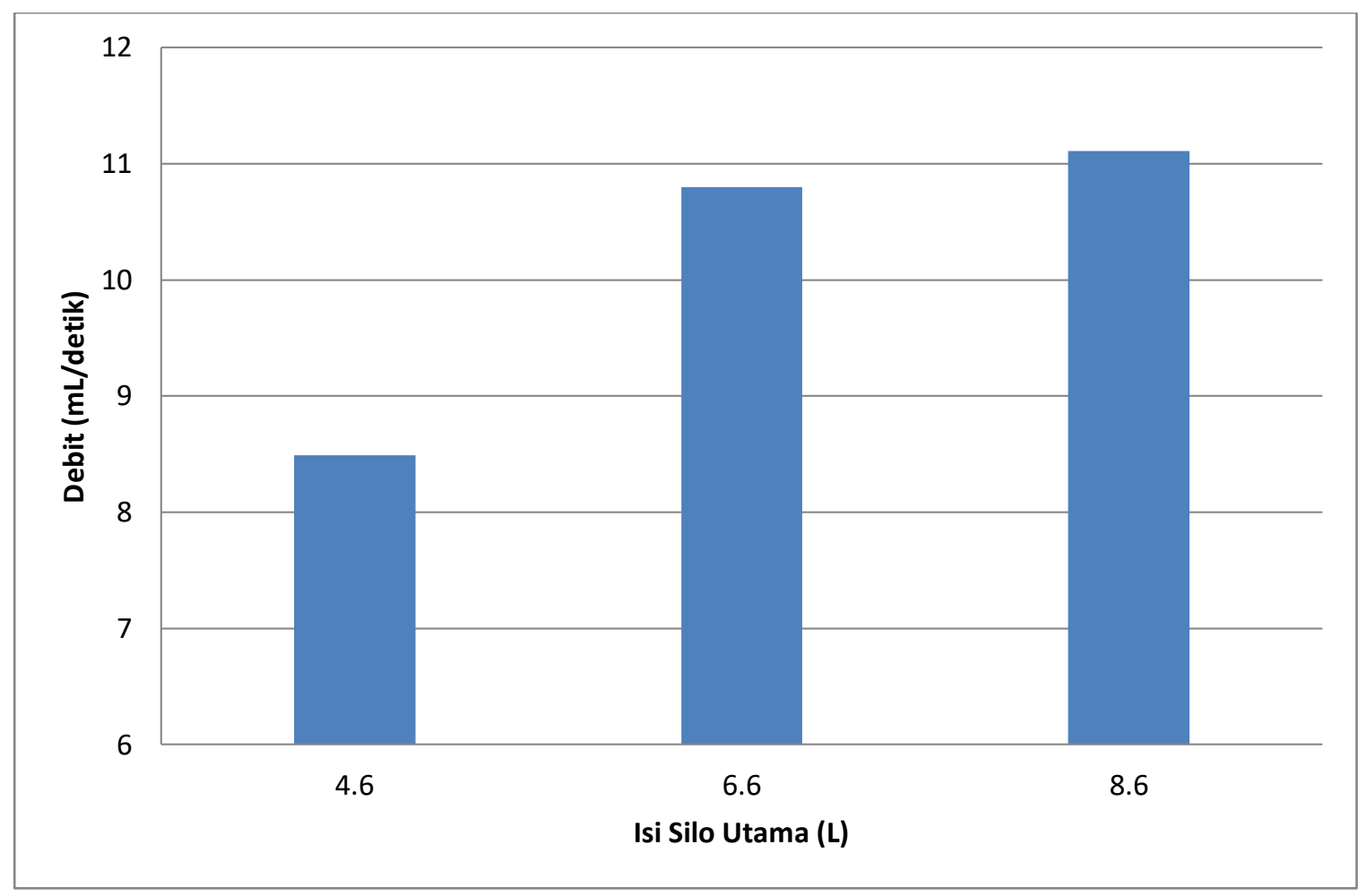

Gambar 9. Grafik Hasil Perhitungan Debit Bubur Kertas Menuju Silo 2

\subsection{Perhitungan Daya dan Konsumsi Energi Solenoid Valve}

Selanjutnya untuk menghitung daya listrik dan energi yang dikonsumsi solenoid valve pada saat pengisian silo dapat dilakukan perhitungan sebagai berikut: 


$$
\begin{aligned}
& P=U \times I \\
& W=P \times t
\end{aligned}
$$

Dimana:

$$
\begin{aligned}
& \mathrm{P}=\text { Daya (Watt) } \\
& \mathrm{W}=\text { Energi (Joule) } \\
& \mathrm{U}=\text { Tegangan (Volt) } \\
& \mathrm{I}=\text { Arus (Ampere) } \\
& \mathrm{t}=\text { Waktu pengisian (detik) }
\end{aligned}
$$

Hasil perhitungan tersebut disajikan pada Tabel 6 di bawah ini.

Tabel 6. Hasil Perhitungan Daya dan Energi Solenoid Valve

\begin{tabular}{cccccc}
\hline Isi Silo Utama (L) & $\begin{array}{c}\text { Waktu } \\
\text { (detik) }\end{array}$ & $\begin{array}{c}\text { Tegangan } \\
(\mathbf{V})\end{array}$ & $\begin{array}{c}\text { Arus } \\
(\mathbf{A})\end{array}$ & $\begin{array}{c}\text { Daya } \\
(\mathbf{W})\end{array}$ & $\begin{array}{c}\text { Energi } \\
(\mathbf{J})\end{array}$ \\
\hline $\mathbf{1 2}$ & 273,2 & 24,02 & 0,21 & 5,04 & $1.376,9$ \\
\hline $\mathbf{1 0}$ & 287,6 & 24,02 & 0,21 & 5,04 & $1.449,5$ \\
\hline $\mathbf{8}$ & 305,8 & 24,02 & 0,21 & 5,04 & $1.541,2$ \\
\hline Isi Silo Utama (L) & $\begin{array}{c}\text { Waktu } \\
\text { (detik) }\end{array}$ & $\begin{array}{c}\text { Tegangan } \\
(\mathbf{V})\end{array}$ & $\begin{array}{c}\text { Arus } \\
(\mathbf{A})\end{array}$ & $\begin{array}{c}\text { Daya } \\
(\mathbf{W})\end{array}$ & $\begin{array}{c}\text { Energi } \\
(\mathbf{J})\end{array}$ \\
\hline $\mathbf{8 , 6}$ & 306 & 24,02 & 0,21 & 5,04 & $1.542,2$ \\
\hline $\mathbf{6 , 6}$ & 314,8 & 24,02 & 0,21 & 5,04 & $1.586,5$ \\
\hline $\mathbf{4 , 6}$ & 400,2 & 24,02 & 0,21 & 5,04 & $2.017,2$ \\
\hline
\end{tabular}

\section{KESIMPULAN}

Setelah melakukan penelitian dan pengujian untuk mengetahui performa dari solenoid valve yang digunakan pada alat simulasi silo viscose, dapat disimpulkan bahwa:

1. Solenoid valve dapat digunakan untuk mengontrol pengisian viscose ke dalam silo.

2. Debit viscose yang mengalir pada alat simulasi tersebut dipengaruhi oleh volume viscose yang terdapat pada silo.

3. Daya listrik pada solenoid valve saat pengisian silo tetap atau konstan, namun terjadi kenaikan konsumsi energi seiring dengan berkurangnya volume viscose di dalam silo.

\section{REFERENSI}

[1] A. De Fretes and R. Kurniawan, "Rancang Bangun Prototipe Mesin Cetak Injeksi Dengan Menggunakan Elektro-Pneumatik," vol. 6, no. 2, pp. 2-7, 2009.

[2] M. Zarkasi, S. B. Mulia, and M. Eriyadi, "Performa Solenoid Pada Valve Alat Pengisian Air Minum Otomatis," vol. 3, no. 2, pp. 53-60, 2018.

[3] R. Destu, "Pembuatan Alat Peraga Pneumatik Dengan Sistem Kontrol Elektropneumatik," 2015.

[4] M. E. Yuwono Indro Hatmojo, S.Pd., Programmable Logic Controller (PLC). Yogyakarta, 2015.

[5] I. Chaerunnisa et al., "Aplikasi PLC Pada Alat Pengisian Air Minum Otomatis," vol. 3, no. 2, pp. 61-68, 2018. 